\title{
Effect of Radiofrequency Heating on the Quality of 'Fuyu' Persimmon Fruit as a Treatment for Control of the Mexican Fruit Fly
}

\author{
Maria E. Monzon, Bill Biasi, and Elizabeth J. Mitcham ${ }^{1}$ \\ Department of Plant Sciences, University of California, MS2, One Shields \\ Avenue, Davis, CA 95616-8780
}

Shaojin Wang and Juming Tang
Department of Biological Systems Engineering, Washington State
University, 213 Smith Hall, Pullman, WA 99164-6120

Guy J. Hallman

USDA-ARS, Crop Quality and Fruit Insect Research Unit, 2413 E. Highway 83, Building 200, Weslaco, TX 78596

Additional index words. Anastrepha ludens, commodity treatment, Diospyros kaki, heat, phytosanitary, quarantine

\begin{abstract}
The external and internal quality of 'Fuyu' persimmon fruit (Diospyros kaki L.) was evaluated after heating with radiofrequency (RF) energy to 48,50 , or $52{ }^{\circ} \mathrm{C}$, holding at the target temperatures for durations ranging from 0.5 to 18 minutes, hydrocooling, and ripening at $20{ }^{\circ} \mathrm{C}$ for 12 days. These treatment conditions were identified for control of third instar Mexican fruit fly larvae (Anastrepha ludens). The treatments had no commercially significant effect on firmness, soluble solids content, titratable acidity, or weight loss of the fruit. RF-treated persimmon fruit attained a deeper orange-red skin color than control fruit. There was a greater incidence of slight to moderate flesh browning in fruit heated to 50 and $52{ }^{\circ} \mathrm{C}$ as compared with $48{ }^{\circ} \mathrm{C}$. Calyx browning increased slightly in all RF-treated fruit and was the highest in the longer treatments at each temperature. Heating persimmon fruit with RF to $48{ }^{\circ} \mathrm{C}$ and then holding for 6 or 12 minutes showed the least damage, and the latter treatment was longer than should be required for a quarantine treatment against the third instar Mexican fruit fly. Holding persimmons for 6.6 minutes at $48{ }^{\circ} \mathrm{C}$ should provide control of the Mexican fruit fly and maintain fruit quality. Confirmation tests with infested fruit should be conducted.
\end{abstract}

Persimmon (Diospyros kaki L.) fruit are host to various quarantined pests, including various fruit flies, lightbrown apple moth, and longtailed mealybug (Dentener et al., 1996; Paull and Armstrong, 1994), which limit fruit export and marketability. For persimmon fruit grown in Southern California, the Mexican fruit fly (Anastrepha ludens), a sporadic pest, can disrupt export of fruit from the local area. A reliable quarantine treatment is needed to prevent disruptions in trade and may require Probit 9 security, a mortality rate of $99.9968 \%$.

Quarantine control can be met with chemical treatments, most commonly with methyl

Received for publication 19 June 2006. Accepted for publication 26 Aug. 2006.

This research was supported by the California Department of Food and Agriculture (CDFA) under Research Agreement 02-0652 and USDA-NRI (05-35503-16223).

We thank Stan Tuffs of Tuffs Ranch for providing the persimmon fruit. We also thank Adel Kader and Marita Cantwell of the University of California, Davis, for their review and suggestions.

${ }^{1}$ To whom reprint requests should be addressed; e-mail ejmitcham@ucdavis.edu. bromide fumigation. There is increased interest in finding alternatives to the use of methyl bromide as a postharvest fumigant, mostly because of its damage to the ozone layer and phytotoxicity to some fruits. Controlled atmosphere treatments have been studied for 'Fuyu' persimmons as an alternative treatment. 'Fuyu' persimmon fruit tolerated exposure for $7 \mathrm{~d}$ to $40 \% \mathrm{CO}_{2}$, which could be a potential insecticidal treatment (Mitcham et al., 1997), but tests of this treatment to meet quarantine security levels must still be conducted for a range of pests. Gamma irradiation has also been tested with limited success. 'Fuyu' persimmons were irradiated with 300 and 1000 Gy. The treatments with $1000 \mathrm{~Gy}$ in polybags stimulated $\mathrm{CO}_{2}$ and ethylene production compared with control fruit (Wheeler and Packer, 1989), indicating fruit stress. Skin browning was also observed after 2 weeks of cold storage on fruit that had been $\gamma$-irradiated with 1000 Gy in polybags (Wheeler and Packer, 1989). Cold treatment has been used commercially as a quarantine treatment to control Mediterranean fruit fly (Ceratitis capitata) infestations in persimmon fruit exported from Italy or Jordan (Paull and Armstrong, 1994). Cold storage is a possible quarantine treatment to control the Mexican fruit fly. Cold treatments that may achieve Probit 9 control of Mexican fruit fly include $18 \mathrm{~d}$ at $0.55^{\circ} \mathrm{C}, 20 \mathrm{~d}$ at $1{ }^{\circ} \mathrm{C}$, or $22 \mathrm{~d}$ at $1.7{ }^{\circ} \mathrm{C}$ (APHIS, 2003; Hallman, 1999). However, these long-term cold storage treatments require significant time and may have deleterious effects on fruit quality by causing chilling injury (CI), thereby limiting fruit marketability.

Hot water dips and hot air treatments have been reported as possible quarantine treatments to control lightbrown apple moth (Epiphyas postvittana) and longtailed mealybugs (Pseudococcus longispinus) on persimmon fruit exported from New Zealand to Japan (Dentener et al., 1996; Lay-Yee et al., 1997). These pests are likely found on the surface of persimmon fruit or underneath the calyx. Consequently, they are directly exposed to heat in short-time surface heat treatments that may have little effect on fruit quality. On the other hand, the Mexican fruit fly is an internal pest that would require longer heat treatments with hot water or hot air to heat the center of the fruit to desired lethal temperatures. These longer exposure times are the result of the slow transfer of heat by conduction, sometimes resulting in a very small window between fruit quality and efficacy against pests; thus, shorter heat treatments are desired.

Radiofrequency (RF) energy involves volumetric heating of commodities, in which electromagnetic waves directly interact with the commodity interior to generate heat through molecular friction, consequently raising temperatures much faster and more evenly (Tang et al. 2000). For fresh fruits, RF heating would have the advantage of direct heating of internal pests (Wang et al., 2003), thus shortening the exposure of fruits to high temperatures that could reduce fruit damage. Recently, Hallman et al. (2005) reported in vitro thermal mortality of third instar Mexican fruit fly larvae using a heating block system. The heating block system heated the insects in a controlled narrow heating space between two metal plates closely mimicking the heating rate of insects generated by RF energy treatments (Wang et al., 2002). These in vitro heating block system tests provided the temperature and timeframe necessary to generate the thermal death mortality curve for the Mexican fruit fly (Hallman et al., 2005), which can be used as a guide to conduct further heat treatments. The objective of this study was to determine the tolerance of 'Fuyu' persimmons to RF heating treatments based on the thermal death mortality curve for the Mexican fruit fly and determine if a RF insect control treatment would be feasible.

\section{Materials and Methods}

Fruit availability and storage before treatment. Persimmon fruit were harvested from a commercial orchard in Winters, Calif., 
on 5 and 12 Nov. 2003. After harvest, fruit were transported to the Postharvest Laboratory at the University of California, Davis, where they were sorted for size (150-200 g), color uniformity, and absence of calyx damage and surface defects. A total of 352 fruit per harvest was stored in chambers ventilated with humidified, ethylene-free air at $20{ }^{\circ} \mathrm{C}$. The fruit were divided into two groups, one group was treated after $24 \mathrm{~h}$ and the second group after $48 \mathrm{~h}$ of harvest, because it was not possible to conduct all treatments and replicates on the same day. At harvest, persimmon fruit had an average of $16.6 \pm 0.1 \%$ total soluble solids content, a hue angle of $69.9 \pm 4.0$ denoting an orange-yellow skin color, and the firmness was $66 \pm 7.5 \mathrm{~N}$ penetration force.

Treatments. Persimmon fruit were heated with a $27-\mathrm{MHz}, 12-\mathrm{kW}$ batch RF machine (Strayfield International Limited, Wokingham, U.K.). A 13-L container was used to hold the fruit submerged in a saline $(\mathrm{NaCl})$ solution of distilled water while circulating during RF exposure (Birla et al., 2004). The saline solution was used as a medium to avoid overheating of fruit at the contact points with other fruits and to assure heating uniformity by matching the dielectric properties of the fruit with those of the water based on its electrical conductivity (EC). Persimmon fruit were placed into the container and covered with an acrylic top plate to ensure fruit submersion in the $20{ }^{\circ} \mathrm{C}$ saline solution and proper fruit rotation. A centrifugal transfer pump $\left(245 \mathrm{~W}, 0.0031 \mathrm{~m}^{3} \cdot \mathrm{s}^{-1}\right.$, ATM Bronze Centrifigal Pump, American Machine and Tool Co., Royersford, Pa.) permitted solution rotation inside the container. Water jets mounted on the periphery of the container forced the fruit to rotate on their own axis while circulating in the container. These motions helped to improve RF heating uniformity (Birla et al., 2004).

Initial tests showed that with a water EC of $56 \mathrm{mS} \cdot \mathrm{m}^{-1}\left(0.035 \% \mathrm{NaCl}\right.$ at $\left.20{ }^{\circ} \mathrm{C}\right)$, the saline solution and the fruit would heat evenly at a rate of $6.0 \pm 0.5{ }^{\circ} \mathrm{C} \mathrm{min}-1$ and $\mathrm{RF}$ power of $9.6 \mathrm{~kW}$ with low temperature variation $\left(\approx 2{ }^{\circ} \mathrm{C}\right)$ within and among the fruit. Water temperature at the end of RF treatments was $\approx 1.5$ to $2{ }^{\circ} \mathrm{C}$ higher than the fruit temperature. For the final experiments, the time when fruit temperature should have reached the target temperature was determined by monitoring the heating rate of the saline solution, which was heated 1.5 to $2{ }^{\circ} \mathrm{C}$ warmer than the target fruit temperature so that the coolest temperature within the fruit would be at or higher than the target temperature. A fiberoptic probe (FISO Technologies, Quebec) with $\pm 0.5^{\circ} \mathrm{C}$ accuracy and response time of less than $1.5 \mathrm{~s}$ inserted in the container $3 \mathrm{~cm}$ below the water level was used to monitor the saline solution temperature. For each treatment, eight persimmon fruit were heated at one time because of space limitations inside the container; each of these heat exposures was considered as a treatment replication. To increase the replicates, each treatment was repeated two times within each of the two harvest dates and each of the two delay periods ( 24 and $48 \mathrm{~h}$ ) to have a total of eight replicates per treatment.

Research by USDA ARS, Weslaco, Texas, and Washington State University, Pullman, using a heating block system determined the in vitro thermal-death mortality curve (time at each temperature required for $100 \%$ mortality) for 600 third instar Mexican fruit fly larvae, the most heat-resistant life stage (Hallman et al., 2005). Preliminary in vitro thermal death kinetic data for third instar Mexican fruit flies indicated that the required minimum times for $100 \%$ mortality of 600 insects were $6.0,1.5$, and $0.5 \mathrm{~min}$ at 48,50 , and $52{ }^{\circ} \mathrm{C}$, respectively. We selected a total of nine treatments to determine the tolerance of persimmon fruit to RF heating. The exposure times at each temperature were based on the minimum time required for $100 \%$ mortality (phytosanitary control) plus two longer exposure times to determine the upper limit of fruit tolerance (Table 1). During RF treatment, the saline solution and fruit were heated from $20^{\circ} \mathrm{C}$ to 48,50 , or $52^{\circ} \mathrm{C}$ (Fig. 1). After reaching the target temperature, the fruit were held in the hot water for the selected holding times. Untreated fruit and fruit treated in water at $24{ }^{\circ} \mathrm{C}$ for $6 \mathrm{~min}$ (approximate time to RF-heat fruit from $20{ }^{\circ} \mathrm{C}$ to target temperature) were included as controls.

Immediately after RF heating and the desired holding time at the target temperature, fruit were hydrocooled by pumping $0{ }^{\circ} \mathrm{C}$ water into the container while draining the hot water until the water temperature decreased to $30{ }^{\circ} \mathrm{C}$ (Fig. 1). Fruit were then transferred to a $15^{\circ} \mathrm{C}$ cold water bath and held for $20 \mathrm{~min}$ to promptly remove heat from the fruit. The internal temperature decreased to $\approx 25{ }^{\circ} \mathrm{C}$ after $20 \mathrm{~min}$ and the fruit were fan-dried to remove surface moisture. All fruit from each treatment replication were placed together in a 3.78-L jar connected to a flow board, which supplied a uniform flow of humidified $(90 \%$ to $95 \% \mathrm{RH}$ ), ethylene-free air at $20{ }^{\circ} \mathrm{C}$, and $150 \mathrm{~mL} \cdot \mathrm{min}^{-1}$ for $12 \mathrm{~d}$ at $20{ }^{\circ} \mathrm{C}$ to determine effects of the heat treatment on fruit ripening and condition. During ripening, the outlet gases were monitored for $\mathrm{CO}_{2}$ (daily) and $\mathrm{C}_{2} \mathrm{H}_{4}$ (every $2 \mathrm{~d}$ ). $\mathrm{CO}_{2}$ concentrations were measured with an IR gas analyzer (Horiba VIA 510; Horiba Instruments Inc., Irvine, Calif.), and $\mathrm{C}_{2} \mathrm{H}_{4}$ concentrations were measured using a gas chromatograph (Carl Gas Chromatograph model 211; Chandler Engineering, Tulsa, Okla.) with a flame ionization detector using $\mathrm{N}_{2}$ as the carrier gas at $80{ }^{\circ} \mathrm{C}$. The column used was $8 \% \mathrm{NaCl}$ on alumina F-1 (Supelco, Bellefonte, Pa.).

Quality evaluations. Fruit skin color was measured on opposite sides of each fruit using a Minolta Chromameter (model CR300; Ramsey, N.J.). The Chromameter was calibrated with a Minolta white calibration plate (No. 22,633,012). The readings were reported as hue values, in which color angles are classified as red $\left(0^{\circ}\right)$, yellow $\left(90^{\circ}\right)$, green $\left(180^{\circ}\right)$, blue $\left(270^{\circ}\right)$, or an intermediate color between any pair of these colors. The skin of each fruit was removed on two opposite sides
Table 1. Target temperatures and holding times for radiofrequency treatments designed to provide $100 \%$ mortality of Mexican fruit fly third instar larvae in 'Fuyu' persimmon and two extra timings designed to test the upper limit of fruit tolerance to the treatment.

\begin{tabular}{lcccc}
\hline & \multicolumn{4}{c}{ Holding times (min) } \\
\cline { 2 - 5 } $\begin{array}{l}\text { Target } \\
\text { temp }\left({ }^{\circ} \mathrm{C}\right)\end{array}$ & Control & TDT $^{\mathrm{z}}$ & $\begin{array}{c}\text { Extra } \\
\text { timing 1 }\end{array}$ & $\begin{array}{c}\text { Extra } \\
\text { timing 2 }\end{array}$ \\
\hline Untreated & 0 & - & - & - \\
24 & 6 & - & - & - \\
48 & - & 6 & 12 & 18 \\
50 & - & 1.5 & 3 & 4.5 \\
52 & - & 0.5 & 1 & 2 \\
\hline
\end{tabular}

${ }^{z}$ Thermal death time (TDT) necessary to reach $100 \%$ mortality of 600 third instar Mexican fruit fly larvae (Hallman et al., 2005).

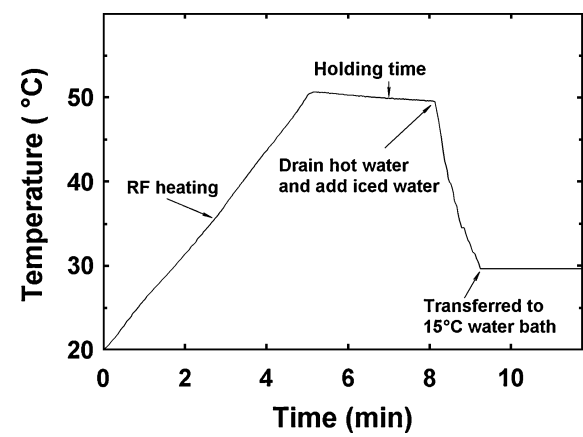

Fig. 1. Temperature of saline water solution during radiofrequency heating and hydrocooling of 'Fuyu' persimmon fruit. Fruit temperature was similar to water temperature after treatment. Water and fruit were heated from 20 to $50 \pm 0.5$ ${ }^{\circ} \mathrm{C}$, held at $50{ }^{\circ} \mathrm{C}$ for $3 \mathrm{~min}$, and hydrocooled to $30{ }^{\circ} \mathrm{C}$ before transfer to a $15^{\circ} \mathrm{C}$ water bath. Heating rate was $6^{\circ} \mathrm{C} \mathrm{min}{ }^{-1}$.

and fruit firmness was measured as resistance to penetration with an $8-\mathrm{mm}$ probe using a Fruit Texture Analyser (Güss, South Africa). Juice was extracted from wedges cut from stem to blossom end from a composite of two fruit from the eight fruit used for each replication per harvest, delay period, and treatment for determination of soluble solids content (SSC) and titratable acidity (TA); these data were averaged within each treatment replication to have a total of eight replicates per treatment. Percent SSC was determined by a digital refractometer (Abbe model 10,450; American Optical, Buffalo, N.Y.) and TA (malic acid equivalents) by an automatic titration system (TIM 850; Radiometer, Copenhagen, Denmark).

After ripening at $20^{\circ} \mathrm{C}$ for $12 \mathrm{~d}$, persimmon fruit were evaluated for external and internal quality, and a hedonic scale was used to determine the severity score for the fruit that had damage. Skin browning and shrivel were evaluated on a scale of 0 to 3 in which $0=$ none, $1=$ slight $(1 \%$ to $10 \%$ of fruit surface), $2=$ moderate $(11 \%$ to $25 \%$ of fruit surface), $3=$ severe ( $>25 \%$ of fruit surface). Calyx browning or drying was evaluated on a scale of 0 to 4 in which $0=$ none, $1=$ very slight (slight browning at the edges, $1 \%$ to $10 \%), 2=$ slight $(11 \%$ to $30 \%$ of surface area), $3=$ moderate $(31 \%$ to $60 \%$ of surface 
area), $4=$ severe $(>60 \%$ surface area). Fruit were cut in half at the equator and flesh browning was evaluated on the cut surface of one half on a scale of 0 to 4 in which $0=$ none, $1=$ very slight $(1 \%$ to $10 \%$ of surface area, very center of the fruit), $2=$ slight $(11 \%$ to $20 \%$ of surface area), $3=$ moderate $(21 \%$ to $40 \%$ of surface area), $4=$ severe $(>40 \%$ surface area). Internal browning of flesh began in the fruit center and spread outward. Decay development was evaluated as $0=$ none and 1 = some decay. For all external subjective scales, except decay, ratings greater than 2 (slight) were considered commercially unacceptable.

Statistical analysis. Fruit quality was analyzed using a randomized complete block design consisting of two harvest dates, each being subjected to two delay periods before treatment ( 24 and $48 \mathrm{~h}$ after harvest). These two variables were considered as blocks. Within each harvest delay period combination, there were a total of nine RF treatments and two controls (Table 1), which were replicated twice, giving a total of eight replicates per treatment. For each quality trait, the average of the eight fruit from each experimental unit was considered as a replicate. Analysis of variance was computed by SAS Version 9 (SAS Institute, Cary, N.C.). Least square means were used when there were missing values in the treatments. Mean comparisons between the untreated control fruit and each treatment were performed using Dunnett with a low experiment-wise error rate $(\alpha=0.05)$.

\section{Results and Discussion}

Harvest 1 and harvest 2 showed similar ethylene production and respiration rate patterns. Ethylene production was lower than $0.3 \mu \mathrm{L} \mathrm{kg} \cdot \mathrm{h}^{-1}$ throughout the ripening period at $20{ }^{\circ} \mathrm{C}$ and was not different among the treatments (data not shown). The respiration rate of untreated persimmon fruit was 8.9 to $9.2 \mathrm{~mL} \mathrm{CO} 2 \mathrm{~kg} \cdot \mathrm{h}^{-1}$ throughout the ripening period at $20^{\circ} \mathrm{C}$. The maximum mean respiration rate $(\mathrm{n}=8)$ was 6,5 , and $10 \mathrm{~mL} \mathrm{CO}_{2}$ $\mathrm{kg} \cdot \mathrm{h}^{-1}$ higher in RF-treated than in untreated fruit 2,6 , and $12 \mathrm{~d}$ after treatment, respectively (Table 2). After $2 \mathrm{~d}$ at $20^{\circ} \mathrm{C}$, all the RFtreated fruit had higher respiration rates compared with the untreated fruit, but the respiration rate decreased after day 6 in some treated fruit indicating that the fruit had begun to recover from the heat stress. Mangoes also recovered from heat stress after $4 \mathrm{~d}$ at $20{ }^{\circ} \mathrm{C}$ after vapor-heat treatment at $46{ }^{\circ} \mathrm{C}$ for $4 \mathrm{~h}$ (Mitcham and McDonald, 1993). Persimmon respiration rates were highest in fruit heated to $52{ }^{\circ} \mathrm{C}$, particularly after $12 \mathrm{~d}$ at $20{ }^{\circ} \mathrm{C}$, and these remained significantly elevated. However, fruit heated to $50{ }^{\circ} \mathrm{C}$ for 1.5 min also showed higher respiration rates after $12 \mathrm{~d}$ at $20{ }^{\circ} \mathrm{C}$ compared with the untreated fruit. The higher respiration rates resulting from RF treatments indicate fruit stress and correlates with the internal damage observed for the same treatments. Heat stress has also been observed in vapor-heated mangoes in which it was attributed to higher respiration rates after treatment (Mitcham and McDonald, 1993) and to the physiological damage of the internal tissues (Mitcham and McDonald, 1997).

Analysis of variance showed that persimmon skin color (hue), firmness, SSC, calyx browning, and flesh browning were significantly different $(\alpha=0.05)$ among the treatments (Table 3, Figs. 2 and 3). Calyx browning and flesh browning were both highly significant for treatment $(P<0.0001)$.

Treatment of persimmon fruit at $48{ }^{\circ} \mathrm{C}$, especially the longer exposure times, resulted in an increase in orange-red color as indicated by a decrease in hue angle compared with the untreated fruit (Table 3). This increase in orange-red color was also seen in fruit heated to $50{ }^{\circ} \mathrm{C}$ for 1.5 or $3 \mathrm{~min}$ and to 52 ${ }^{\circ} \mathrm{C}$ for $2 \mathrm{~min}$. Similarly, an increase in yellow skin color intensity was observed in heattreated 'Kensington' mangoes in which it was attributed to enhanced ripening (Jacobi and Giles, 1997; Jacobi et al., 1995). An increase in skin color of 'Fuyu' persimmon fruit from brilliant orange-yellow to deep orange indicates changes in fruit maturity (Beede, 1983 ) or ripeness. RF-treated fruit also tended to be softer.

$\mathrm{RF}$ treatment had no effect on fruit TA or weight loss and had little effect on SSC (Table 3). Although the analysis of variance showed a significant overall effect of treatment on fruit firmness $(P=0.04)$, there were no significant differences between the untreated control fruit and the RF treated fruit (Table 3). There was a trend toward lower fruit firmness with RF treatments at the higher temperatures $\left(50\right.$ and $52{ }^{\circ} \mathrm{C}$ ), but our results show that fruit from all treatments were greater than $22 \mathrm{~N}$ penetration force, the firmness minimum threshold acceptable to consumers of 'Fuyu' persimmons (USDA, 2005). Fruit heated to $50{ }^{\circ} \mathrm{C}$ for $1.5 \mathrm{~min}$ and $52{ }^{\circ} \mathrm{C}$ for 2 min had the lowest firmness. Fruit treated at

Table 2. Mean values for 'Fuyu' persimmon fruit respiration rate $(n=8)$ after radiofrequency treatment after 2,6 , or $12 \mathrm{~d}$ of ripening at $20^{\circ} \mathrm{C}$.

\begin{tabular}{|c|c|c|c|c|}
\hline \multicolumn{2}{|c|}{ Treatment } & \multicolumn{3}{|c|}{ Respiration Rate $\left(\mathrm{mL} \mathrm{CO} \mathrm{kg}^{-1} \mathrm{~h}^{-1}\right)$} \\
\hline Temperature $\left({ }^{\circ} \mathrm{C}\right)$ & Time $(\min )$ & Day 2 & Day 6 & Day 12 \\
\hline $\mathrm{z}^{\mathrm{z}}$ & - & 9.2 & 8.9 & 8.9 \\
\hline 24 & 6 & 9.2 & 8.7 & 8.3 \\
\hline \multirow[t]{3}{*}{48} & 6 & $11.4^{* y}$ & 10.6 & 12.1 \\
\hline & 12 & $12.6^{*}$ & 10.9 & 11.3 \\
\hline & 18 & $13.2^{*}$ & $12.0^{*}$ & 11.9 \\
\hline \multirow[t]{3}{*}{50} & 1.5 & $13.6^{*}$ & $13.6^{*}$ & $16.4^{*}$ \\
\hline & 3 & $12.7^{*}$ & 11.1 & 12.5 \\
\hline & 4.5 & $13.3^{*}$ & $12.3^{*}$ & 12.9 \\
\hline \multirow[t]{3}{*}{52} & 0.5 & $14.9^{*}$ & $13.1 *$ & $16.1^{*}$ \\
\hline & 1 & $14.9^{*}$ & $13.8 *$ & $19.1 *$ \\
\hline & 2 & $15.2^{*}$ & $14.3 *$ & $19.0 *$ \\
\hline \multicolumn{2}{|c|}{ Overall $P$ value } & $<0.0001$ & $<0.0001$ & $<0.0001$ \\
\hline \multicolumn{2}{|c|}{ Control vs. treatment MSD } & 1.9 & 2.8 & 5.4 \\
\hline
\end{tabular}

${ }^{\mathrm{z} U n t r e a t e d ~ c o n t r o l ~ f r u i t . ~}$

${ }^{y}$ Asterisk (*) denotes treatment mean was significantly different from untreated control at $\alpha=0.05$ based on Dunnett minimum significant difference.

${ }^{\mathrm{x}}$ Dunnett mean significant difference (MSD) used to compare the untreated control versus a given treatment.

Table 3. Mean values for quality traits $(n=8)$ on the effect of radiofrequency treatments on persimmon skin color, firmness, soluble solids, titratable acidity, and weight loss after $12 \mathrm{~d}$ of ripening at $20{ }^{\circ} \mathrm{C}$.

\begin{tabular}{|c|c|c|c|c|c|c|}
\hline \multicolumn{2}{|c|}{ Treatment } & \multirow{2}{*}{$\begin{array}{l}\text { Skin Color } \\
\text { (Hue) }\end{array}$} & \multirow{2}{*}{$\begin{array}{c}\text { Firmness } \\
\text { (Newtons) }\end{array}$} & \multirow[b]{2}{*}{$\mathrm{SSC}^{\mathrm{z}}(\%)$} & \multirow[b]{2}{*}{$\mathrm{TA}^{\mathrm{y}}(\%)$} & \multirow[b]{2}{*}{ Wt loss $(\%)$} \\
\hline Temperature $\left({ }^{\circ} \mathrm{C}\right)$ & Time (min) & & & & & \\
\hline $\mathrm{C}^{\mathrm{x}}$ & - & 61.2 & 44.6 & 17.1 & 0.10 & 0.7 \\
\hline 24 & 6 & 61.3 & 46.2 & 17.3 & 0.08 & 1.1 \\
\hline \multirow[t]{3}{*}{48} & 6 & 58.6 & 42.6 & 17.1 & 0.09 & 0.8 \\
\hline & 12 & $57.7 * w$ & 41.4 & 17.1 & 0.10 & 0.8 \\
\hline & 18 & $57.3 *$ & 41.4 & 17.1 & 0.12 & 0.8 \\
\hline \multirow[t]{3}{*}{50} & 1.5 & $57.6^{*}$ & 34.0 & 16.7 & 0.10 & 1.1 \\
\hline & 3 & $58.2 *$ & 38.5 & 17.1 & 0.10 & 0.8 \\
\hline & 4.5 & 59.1 & 37.5 & 16.7 & 0.11 & 0.8 \\
\hline \multirow[t]{3}{*}{52} & 0.5 & 58.8 & 36.4 & 17.0 & 0.13 & 1.0 \\
\hline & 1 & 58.9 & 37.1 & 16.5 & 0.12 & 0.9 \\
\hline & 2 & $57.9^{*}$ & 34.6 & $15.7^{*}$ & 0.11 & 1.3 \\
\hline \multicolumn{2}{|c|}{ Overall $P$ value } & $<0.001$ & 0.04 & $<0.001$ & 0.79 & 0.08 \\
\hline \multicolumn{2}{|c|}{ Control vs. Treatment MSD $^{v}$} & 2.8 & 11.0 & 0.9 & 0.07 & 0.6 \\
\hline
\end{tabular}

zoluble solids content.

'Titratable acidity.

${ }^{x}$ Untreated control fruit.

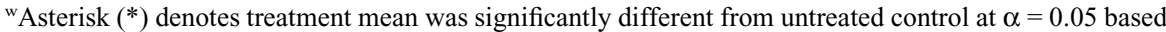
on Dunnett minimum significant difference.

vDunnett mean significant differences (MSD) used to compare the untreated control versus a given treatment. 

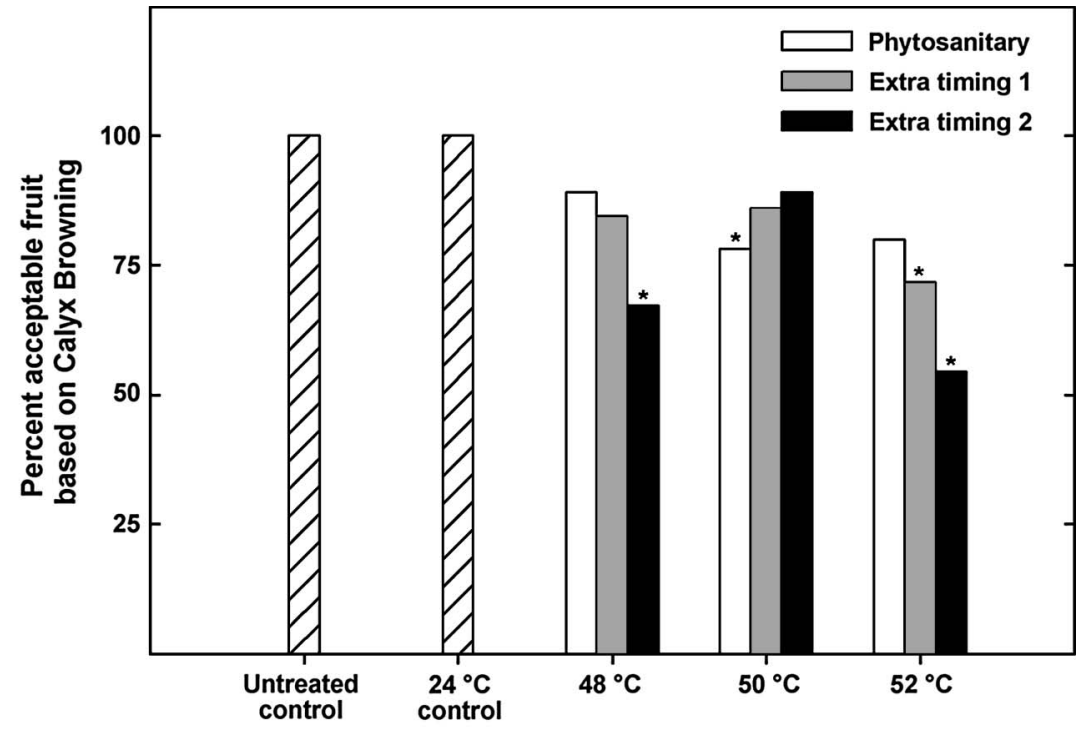

B

Control

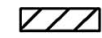

1.2

1.1

Phytosanitary

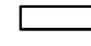

-

-

1.8

2.0

1.8

Extra
timing 1

\section{Extra}

timing 2
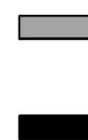

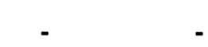

1.9

2.2

1.9

1.9

2.1

Fig. 2. (A) Percent acceptable fruit based on calyx browning severity scores $\leq 2$ after radiofrequency treatment and $12 \mathrm{~d}$ of ripening at $20^{\circ} \mathrm{C}$ for 'Fuyu' persimmon fruit. Fruit were heated from $20^{\circ} \mathrm{C}$ to $48^{\circ} \mathrm{C}(6,12,18 \mathrm{~min}), 50^{\circ} \mathrm{C}(1.5,3,4.5 \mathrm{~min})$, or $52^{\circ} \mathrm{C}(0.5,1,2 \mathrm{~min})$. An asterisk (*) denotes treatment mean was significantly different from untreated control at $\alpha=0.05$ based on Dunnett minimum significant difference $(\mathrm{MSD}=21.3)$. (B) Average calyx browning severity score: $0=$ none, $1=$ very slight (slight browning at the edges, $1-10 \%), 2=$ slight $(11-30 \%$ of surface area), $3=$ moderate $(31-60 \%$ of surface area), $4=$ severe $(>60 \%$ surface area).

$52{ }^{\circ} \mathrm{C}$ for $2 \mathrm{~min}$ also had significantly lower $\mathrm{SSC}$ compared with the untreated fruit. These results indicate that the longest treatment at the highest temperature $\left(52{ }^{\circ} \mathrm{C}\right.$ for $\left.2 \mathrm{~min}\right)$ caused the greatest amount of fruit stress.

RF treatments had little effect on the external appearance of persimmon fruit. Skin browning was not significantly affected by treatments $(P=0.1)$ but was observed in some fruit treated at $52{ }^{\circ} \mathrm{C}$ for 1 or $2 \mathrm{~min}$ (data not shown). The browning was slight $(<10 \%$ surface area), and symptoms were localized sunken areas with tissue softening that were not uniformly distributed on the surface of the fruit. Skin browning appeared to result from overheating at contact points between fruit likely incited by slow rotation within the treatment container, possibly because of nonspherical fruit shape (Birla et al., 2004).

Calyx browning manifested as very slight to moderately brown and dry areas on the calyx. For all RF treatments, the average calyx browning severity of affected fruit was slight to moderate compared with the untreated fruit that had very slight calyx browning (Fig. 2B). There was a higher percentage of calyx browning on all RFtreated fruit as compared with untreated control fruit (data not shown). However, only fruit heated to $52^{\circ} \mathrm{C}$ for 1 or $2 \mathrm{~min}, 50^{\circ} \mathrm{C}$ for
$1.5 \mathrm{~min}$, or $48^{\circ} \mathrm{C}$ for $18 \mathrm{~min}$ had significantly less acceptable fruit based on the percentage of fruit with calyx browning severity scores $\leq 2$ compared with the untreated control fruit (Fig. 2A). Fruit heated to $48{ }^{\circ} \mathrm{C}$ for up to 12 min had more than $85 \%$ of commercially acceptable fruit based on calyx browning. We believe that the $\mathrm{NaCl}$ solution or the drying process may have resulted in some damage to the calyx, and these parameters should be controlled in future studies.

RF treatments had no significant effect on shrivel or decay symptoms $(P=0.8$ and 0.5 , respectively). Shrivel was not observed in this study, perhaps because fruit were immediately hydrocooled after RF treatments and were then ripened immediately at $90 \%$ to $95 \%$ relative humidity. A low level of decay incidence was observed when fruit were heated to $52{ }^{\circ} \mathrm{C}$ for $2 \mathrm{~min}(6.3 \%)$, but this was not significantly different from control fruit that had no decay (data not shown).

Some RF treatments affected flesh quality, resulting in internal browning beginning in the center of the fruit and expanding into the middle of the flesh as severity increased. Persimmon fruit did not tolerate $\mathrm{RF}$ heating to $52{ }^{\circ} \mathrm{C}$, even with a holding period as short as $0.5 \mathrm{~min}$, resulting in a significantly lower percentage of accept- able fruit $(62 \%)$ compared with the control fruit $(100 \%)$ (Fig. 3A). Treatments at $50{ }^{\circ} \mathrm{C}$ resulted in higher percentages of acceptable fruit compared with the fruit heated to 52 ${ }^{\circ} \mathrm{C}$, and the average severity score for affected fruit was lower than for fruit heated to $52{ }^{\circ} \mathrm{C}$ (Fig. 3B). Although heating the fruit to $50{ }^{\circ} \mathrm{C}$ and holding for a period of 3 or 4.5 min resulted in $>80 \%$ acceptable fruit based on flesh browning, holding for 1.5 min at $50{ }^{\circ} \mathrm{C}$ resulted in only $60 \%$ acceptable fruit with an unacceptable average severity score. The reason for this variability in response is unknown but may indicate that RF treatment at $50{ }^{\circ} \mathrm{C}$ has the potential to cause significant fruit damage. Additional work is needed to clarify this point. The percentage of acceptable fruit based on flesh browning scores $\leq 2$ when fruit were heated to $48{ }^{\circ} \mathrm{C}$ was more than $94 \%$ and was not significantly different from untreated control fruit. The severity scores averaged 1.5 , within the range of commercial acceptability (Fig. 3).

$\mathrm{RF}$ heat treatments may reduce CI symptoms during subsequent cold storage and shipping. Many authors have reported that heat treatments can induce chilling tolerance in fruits (Burmeister et al., 1997; Woolf et al., 1997) perhaps as a result of formation of heat shock proteins (HSPs), as has been shown in tomato (Lurie and Klein, 1991) and 'Hass' avocado (Woolf et al., 1995). It has been suggested that development of HSPs could be the reason for CI alleviation in hot watertreated 'Fuyu' persimmons (Lay-Yee et al., 1997). Additional work is needed to determine if RF-heated persimmon fruit have additional protection from CI resulting from HSP formation.

The RF treatment at $48{ }^{\circ} \mathrm{C}$ designed for phytosanitary control of the Mexican Fruit fly did not significantly injure or reduce marketability of 'Fuyu' persimmon fruit, but treatments at $50{ }^{\circ} \mathrm{C}$ were over the limit of fruit marketability as a result of internal browning. Moderate to severe skin browning symptoms have been reported for persimmon fruit heated with air at $47{ }^{\circ} \mathrm{C}$ for more than $3 \mathrm{~h}$ (Woolf et al., 1997) or hot water dips at $47^{\circ} \mathrm{C}$ for more than $1 \mathrm{~h}$ (Burmeister et al., 1997). In contrast, our results showed that there was only a very slight development of skin browning, likely resulting from fruit-to-fruit contact during treatment, which should be avoided with constant fruit movement in a larger commercial treatment system. These results indicate that RF heating may be less damaging than hot air or hot water treatments, perhaps as a result of the shorter exposure to heated environments. Severity of skin browning, calyx browning, and shrivel were relatively minor after RF treatments but were moderate to severe in hot air and hot water-treated fruit (Burmeister et al., 1997; Woolf et al., 1997). In addition to the much shorter treatment time and heat exposure, immediate hydrocooling of persimmon fruit after the heat treatment likely reduced damage from heat compared with air cooling at room temperature as reported in other 


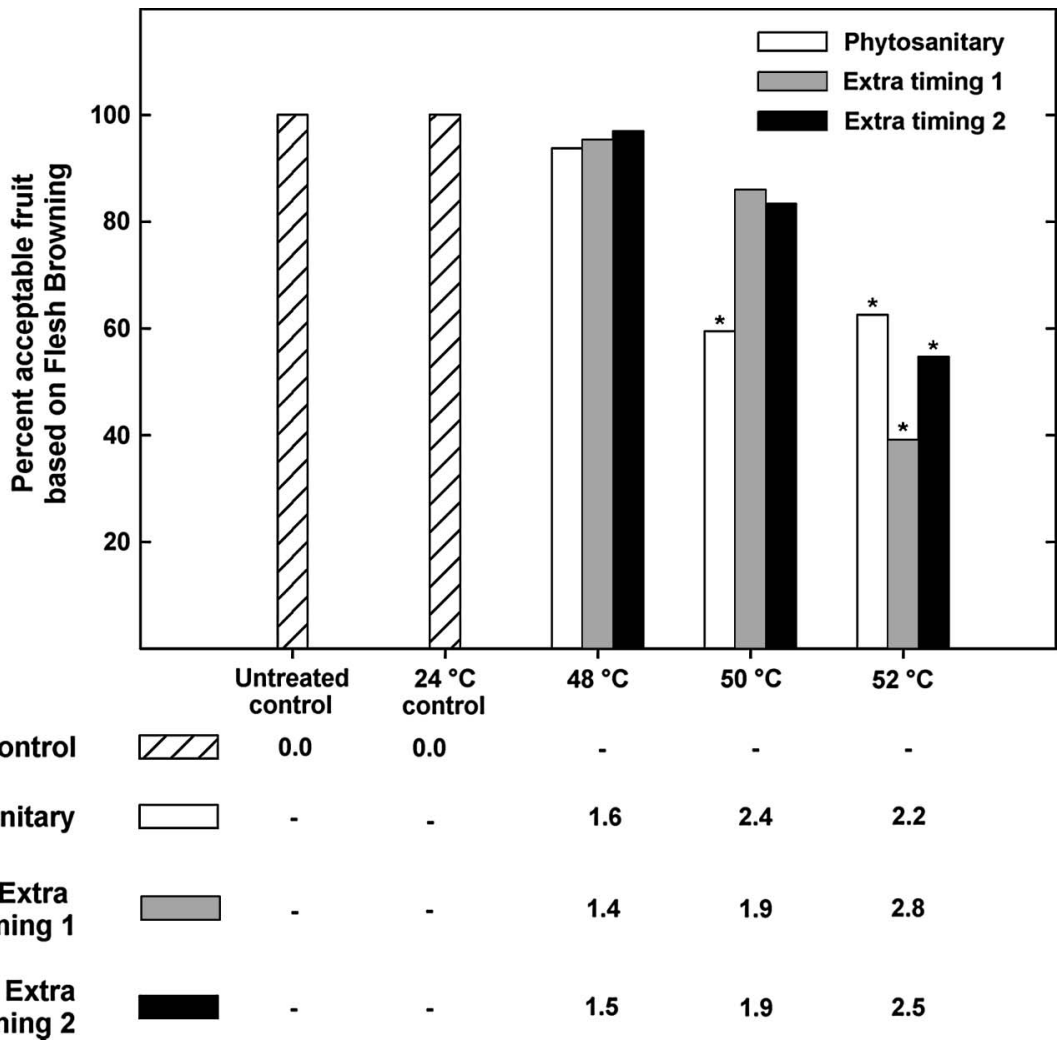

Fig. 3. (A) Percent acceptable fruit based on the flesh browning severity scores $\leq 2$ after radiofrequency treatment and $12 \mathrm{~d}$ of ripening at $20{ }^{\circ} \mathrm{C}$ for 'Fuyu' persimmon fruit. Fruit were heated from $20{ }^{\circ} \mathrm{C}$ to $48^{\circ} \mathrm{C}(6,12,18 \mathrm{~min}), 50^{\circ} \mathrm{C}(1.5,3.0,4.5 \mathrm{~min})$, or $52^{\circ} \mathrm{C}(0.5,1,2 \mathrm{~min})$. An asterisk (*) denotes treatment mean was significantly different from untreated control at $\alpha=0.05$ based on Dunnett minimum significant difference $(\mathrm{MSD}=30.25)$. (B) Internal browning severity score: $0=$ none, $1=$ very slight $(1-$ $10 \%$ of surface area), $2=$ slight (11-20\% of surface area), $3=$ moderate $(21-40 \%$ of surface area), $4=$ severe $(>40 \%$ surface area). Severity scores $>2$ were considered commercially unacceptable.

studies (Burmeister et al., 1997; Lay-Yee et al., 1997; Woolf et al., 1997).

\section{Conclusions}

The most promising RF protocol to obtain phytosanitary control of the third instar Mexican fruit fly in 'Fuyu' persimmon fruit appears to be RF heating to $48{ }^{\circ} \mathrm{C}$ for 6 $\mathrm{min}$, and fruit also tolerated exposure of 12 min without significant injury. The completed heating block studies indicate that the required holding time to achieve Probit 9 security for the third instar Mexican fruit fly should be $6.6 \mathrm{~min}$ after RF heating to $48^{\circ} \mathrm{C}$ (Hallman et al., 2005), indicating that Probit 9 security could be met at $48{ }^{\circ} \mathrm{C}$ within the holding times tolerated by the fruit. Therefore, heating with RF shows potential as a treatment to control the Mexican fruit fly in 'Fuyu' persimmon fruit. However, more efficacy tests are needed to confirm that RF heating of persimmon fruit to $48{ }^{\circ} \mathrm{C}$ would kill Mexican fruit fly larvae within the fruit.
Hallman, G.J., S. Wang, and J. Tang. 2005. Reaction orders for thermal mortality of thirdinstar Mexican Fruit Fly (Diptera: Tephritidae). J. Econ. Entomol. 98:1905-1910.

Jacobi, K.K. and J.E. Giles. 1997. Quality of 'Kensington' mango (Mangifera indica Linn.) fruit following combined vapour heat disinfestation and hot water disease control treatments Postharvest Biol. Technol. 12:285-292.

Jacobi, K.K., L.S. Wong, and J.E. Giles. 1995 'Effect of fruit maturity on quality and physiology of high-humidity hot air-treated 'Kensington' mango (Mangifera indica Linn.). Postharvest Biol. Technol. 5:149-159.

Lay-Yee, M., S. Ball, S.K. Forbes, and A. Woolf. 1997. Hot-water treatment for insect disinfestation and reduction of chilling injury of 'Fuyu' persimmon. Postharvest Biol. Technol. 10: 81-87.

Lurie, S. and J.D. Klein. 1991. Acquisition of lowtemperature tolerance in tomatoes by exposure to high-temperature stress. J. Amer. Soc. Hort Sci. 116:1007-1012.

Mitcham, E.J., M.M. Attia, and W. Biasi. 1997. Tolerance of 'Fuyu' persimmons to low oxygen and high carbon dioxide atmospheres for insect disinfestation. Postharvest Biol. Technol. 10:155-160.

Mitcham, E.J. and R.E. McDonald. 1993. Respiration rate, internal atmosphere, and alcohol and acetaldehyde accumulation in vapor-heated mango fruit. Postharvest Biol. Technol. 3: 77-86.

Mitcham, E.J. and R.E. McDonald. 1997. Effect of postharvest heat treatment on inner and outer tissue of mango fruit. Trop. Sci. 37:193-205.

Paull, R.E. and J.W. Armstrong. 1994. Insect Pests and Fresh Horticultural Products, Treatments and Responses. CABI International, University Press, Cambridge, U.K.

Tang, J., J.N. Ikediala, S. Wang, J.D. Hansen, and R.P. Cavalieri. 2000. High-temperature shorttime thermal quarantine methods. Postharvest Biol. Technol. 21:129-145.

USDA. 2005. USDA, Agricultural Handbook 66. Dec. 2004. http://www.ba.ars.usda.gov/hb66/ title.html.

Wang, S., J. Tang, J.A. Johnson, and J.D. Hansen 2002. Thermal-death kinetics of fifth-instar Amyelois transitella (Walker). J. Stored Prod. Res. 38:427-440.

Wang, S., J. Tang, J.A. Johnson, E. Mitcham, J.D. Hansen, G. Hallman, S.R. Drake, and Y. Wang. 2003. Dielectric properties of fruits and insect pests as related to radio frequency and microwave treatments. Biosystems Eng. 85:201-212.

Wheeler, D.R. and J.E. Packer. 1989. Responses of 'Fuyu' persimmon to $\gamma$-irradiation. HortScience 24:635-637.

Woolf, A.B., S. Ball, K.J. Spooner, M. Lay-Yee, I.B. Ferguson, C.B. Watkins, A. Gunson, and S.K. Forbes. 1997. Reduction of chilling injury in the sweet persimmon 'Fuyu' during storage by dry air heat treatments. Postharvest Biol. Technol. 11:155-164.

Woolf, A.B., C.B. Watkins, J.H. Bowen, M. LayYee, J.H. Maindonald, and I.B. Ferguson. 1995. Reducing external chilling injury in stored 'Hass' avocados with dry heat treatments. J. Amer. Soc. Hort. Sci. 120:1050-1056. 